\title{
A SIMPLE HOME-MADE TURBIDIMETER (HMT) FOR TURBIDITY MEASUREMENTS USING Hyalella curvispina SHOEMAKER 1942 (CRUSTACEA: AMPHIPODA) FOR THE ASSESSMENT OF ENVIRONMENTAL QUALITY OF COASTAL WATERS
}

\author{
María Elena Bouvier ${ }^{1}$, Alberto Pérez ${ }^{2}$ and Pablo Muniz ${ }^{2}$ * \\ ${ }^{1}$ Facultad de Ciencias - UDeLaR , Uruguay \\ Oceanografía y Ecología Marina, IECA \\ (Iguá 4225, Montevideo 11400, Uruguay) \\ ${ }^{2}$ Universidad de la República / Uruguay \\ Sección Oceanografía y Ecología Marina / Facultad de Ciencias - UDeLaR \\ (Iguá 4225, Montevideo 11400, Uruguay)
}

*Corresponding author: pmmaciel@fcien.edu.uy

Turbidity is a measurement of the clarity of water that has been used as an indicator of the environmental health of water bodies (GIPPEL, 1989). This physical property of water is caused mainly by the presence of suspended solids, such as silt, clay, organic matter, plankton, microorganisms and colored substances that cause the incident light to be scattered and absorbed instead of transmitted through the water sample (SADAR, 1996; UNITED STATES, 1999). It has been used as a surrogate measure of suspended solids in water analyses, in monitoring programs of water quality (LEWIS, 1996; SADAR, 1996; ORWIN; SMART, 2005). A detailed description of the principles of turbidity measurement and instrument designs can be found in SADAR (1996).

As an ecological factor, its role is fundamental, affecting many aspects of the trophic webs at different levels: it affects the availability of light and the capability of primary producers being suspended in the water column, the encounter rates between prey and predators, modifies the behavioral responses of prey to control the risk of predation and induces changes in the diet of some piscivorous fishes (DAVIES-COLLEY; SMITH, 2001; ABRAHAMS; KATTENFELD, 2007; CARTER et al., 2010).

Bioturbation (activity of benthic organisms modifying the sediment structure) measured as turbidity generation has been postulated as a sensitive endpoint in studies of sub-lethal responses to assess the toxicity of aquatic sediments (BARTSCH et al., 1999; BRIGGS et al., 2003). Tests that measure sublethal responses allow the detection of effects on biota at low concentrations of contaminants (RAND et al.,
1995). These effects, without being lethal in the short term can lead to ecological changes that affect an organism's long-term ability to survive. They are useful in the analysis of areas with moderate to severe pollution (BRIGGS et al., 2003; ALLEN et al., 2006). When relatively uncontaminated sediments are spiked with a gradient of concentrations of cadmium, copper or PAHs, the turbidity generated by the activity of the organisms exposed to these spiked sediments responded in a concentration-dependent manner (BARTSCH et al., 1999; BRIGGS et al., 2003). Thus organisms affected by the concentrations of contaminants added to the sediments respond by modifying their activity pattern. In applying this type of test, Briggs et al. (2003) using turbidity measuring equipment of simple, inexpensive construction, with amphipods Corophium volutator (Pallas), quickly detected those sediments which would require further analysis to determine the cause of their potential toxicity.

Nevertheless, the use of turbidity as an end point in toxicity testing presents some difficulties, as represented, for example, by grain size which can be a confounding factor in its applicability (BRIGGS et al., 2003). Sand particles sink faster than smaller ones such as silt or clay, and this physical property of a sediment can affect the generation of turbidity by the organisms and therefore the objective of the test, that is to detect sub-lethal toxicity in the target sediment. The undertaking of this test also requires that the number of organisms present per experimental unit should be determined, since different organism 
densities could imply different responses and consequently different turbidity results.

The main objective of this study is to present the Home Made Turbidimeter (HMT), a simple device constructed to adjust this turbidity test to specimens of Hyalella curvispina, an indigenous benthic amphipod of Argentina, Brazil and Uruguay (GONZÁLEZ, 2003; JERGENTZ et al., 2004; GRAÇA et al., 2002). We tested its suitability using it in a turbidity test with clean sediments of different grain size and by analyzing a series of solutions of known turbidity with this instrument to assess its performance

The design of the HMT is illustrated and the principle of its functioning presented. It was made of wood covered with black paper. It consists (Fig. 1) of a rectangular prism - without a base - with two holes in opposite sides in which the lamp (Radium RJLS $2012 \mathrm{SP}, 12 \mathrm{~V}, 20 \mathrm{~W}, 10^{\circ}$, color temperature $3000 \mathrm{~K}$ ) and the photoresistor (CdS Photoconductive cells GL5549) were, respectively, mounted. The photoresistor was placed at $180^{\circ}$ to the incident light and connected to an AVR Butterfly board from Atmel Corporation that measured the amount of light absorbed by the samples.
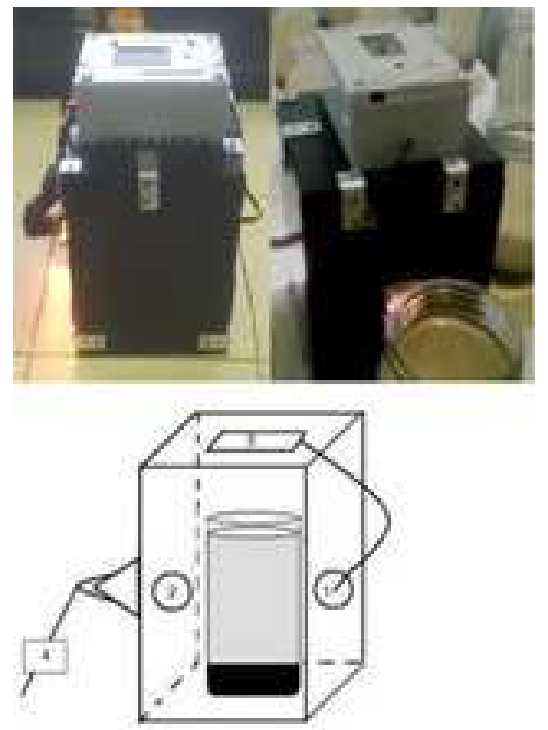

Fig. 1. Photogrpahs of the Home Made Turbidimeter (HMT) and schematic representation with test beaker containing sediment (in black) and water (in grey). The unit is $13 \mathrm{~cm}$ wide and $17 \mathrm{~cm}$ high. 1-Photocell; 2- Lamp; 3- Multimeter; 4- Voltage stabilizer.

To quantify the linearity and precision of the instrument, a series of formazine solutions were analyzed. The standard formazine and the calibration curve were prepared in accordance with USEPA
Method 180.1. Two calibration curves were analyzed: 0-40 FAU (Formazine Attenuation Units) and 0-200 FAU. The background signal was determined by measuring a sample of distilled water.

Amphipods ( $H$. curvispina) were cultured according to Method 100.1 of the American Environmental Protection Agency (USEPA 600/R99/064) adapted to the species Hyalella curvispina. The age of the organisms exposed was 20-25 days because in previous experiments we had determined that organisms of this age were the youngest that could bioturbate the sediment and produce a response that could be measured with the HMT.

Test sediments were collected from two areas of the coastal zone of Uruguay, South America: the silt-clay sediment of the central zone of the Río de la Plata estuary on the Montevideo city coast and the sandy sediment of the Cabo Polonio beach. The sediment was separated into different size fractions by wet sieving. After being separated, the size fractions were oven-dried at a temperature $<40^{\circ} \mathrm{C}$. Five sediments categories were composed according to their granulometric fractions, on a dry weight basis. The sediments were: 100\% fine sand (FS) (125 to 64 $\mu \mathrm{m}$ grain size), $100 \%$ silt and clay (SC) (grain size < $64 \mu \mathrm{m}), 75 \%$ FS-25\% SC, 50\% FS-50\% SC, and $25 \%$ FS-75\% SC

Tests were conducted in commercial glass beakers of $400 \mathrm{ml}$ containing approximately $100 \mathrm{ml}$ of sediment covered by $270 \mathrm{ml}$ of culture water. After the addition of sediment and water, the beakers were maintained under test conditions for 48 hours prior to the addition of the animals. The test beakers were gently aerated by using air tubes 24 hours after the addition of sediment and culture water. To test the effect of varying the number of animals on the turbidity, for each type of sediment we stocked the test beakers with, respectively, $0,10,15$ and 20 organisms/beaker, and conducted five replicates for each organism density. Turbidity measurements were taken before and after the addition of the animals after $3,8,24,32$ and 48 hours of exposure. The light was kept on for 15 seconds to make each measurement. The results were compared by ANOVA when the data met the assumptions of homoscedasticity and normality, otherwise they were analyzed with KruskalWallis's non-parametric test.

At the end (48 h), immediately following the turbidity measurements, a $50 \mathrm{ml}$ sample of the overlying water was carefully collected from each of the beakers with a volumetric glass pipette and filtered through a pre-weighed $0.45 \mathrm{~mm}$ filter paper (Whatman $\mathrm{GF} / \mathrm{C})$. The filter papers were then oven-dried at $105^{\circ} \mathrm{C}$ and reweighed to estimate the amount of sediment suspended in the water. Suspended sediment values were compared to turbidity by simple linear regressions. 
The 0-40 and 0-200 FAU calibration curves demonstrated a good linear correlation $(r=0.9277$ and 0.9889 , respectively) between the concentration of formazine and the turbidity measurements, as shown in Figure 2. The results indicated that the instrument can be used to determine turbidity, with better performance in the range of values above $40 \mathrm{FAU}$.

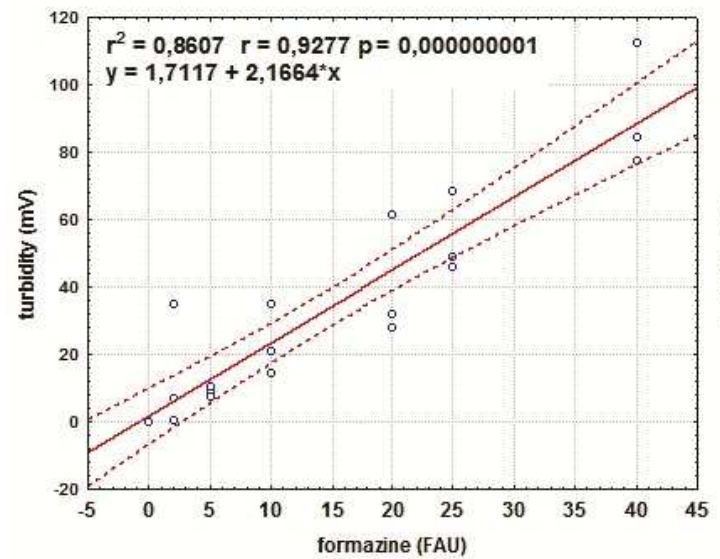

Characterization of the instrument included the determination of the background signal that was made by the analysis of the turbidity of distilled water with the HMT, demonstrating good reproducibility, with the mean turbidity $=151 \mathrm{mV},(\mathrm{n}=32)$ and the standard deviation of the measurements always less than $5 \%$.

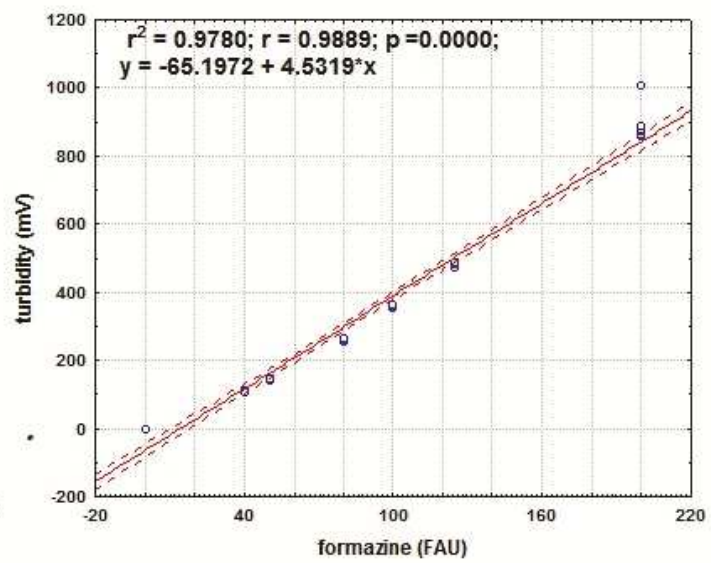

Fig. 2. Calibration curves for the HMT. A) 0-40 FAU; B) 0-200 FAU. Best-fit equations are shown.

For all the sediment categories analyzed, excepting the $100 \% \mathrm{FS}$, the mean turbidity in the control beakers without organisms was lower $(n=5$, ANOVA, $\mathrm{p}<0.05$ ) than the turbidity measured in the beakers with 10,15 and 20 organisms as from 8 hours' exposure. The presence of the animals in the beakers generates a turbidity increment in the overlying water, thus we may conclude that $H$. curvispina is a bioturbator of fine sediments. The grain size of the $100 \%$ FS sediment would be too big to be resuspended by these organisms. Furthermore, as stated by Gippel (1989), the visible light source makes the turbidimeters more sensitive to the scattering due to fine particles. For these reasons, the turbidity in the beakers containing fine sand and 10, 15 and 20 organisms was minimal and not significantly different from that of the treatment without organisms. We can, therefore, conclude that the test (as designed here) is not suitable for analyzing sediment of grain sizes $100 \%$ greater than or equal to fine sand.

The maximum turbidity value was determined in the treatment with 20 organisms and the $25 \%$ FS - $75 \%$ SC sediment category (Fig. 3). The turbidity measured in this test did not differ significantly from that measured in the $100 \%$ SC sediment category. The number of organisms selected to standardize the test was 20 organisms/beaker, because this was the number of organisms that generated a turbidity response that was: the biggest, least variable and capable of being statistically detected by the initial measurements. This is in accordance with the results of Briggs et al. (2003), who selected 20 organisms as the adequate number of animals/beaker for the turbidity test with Corophium volutator.

Significant relationships between turbidity measured at $48 \mathrm{~h}$ of exposure and the total suspended solids concentration (TSS) for the sediments $100 \% \mathrm{SC}$ $(\mathrm{r}=0.9484, \quad \mathrm{p}<0.01), \quad 75 \% \mathrm{FS}-25 \% \mathrm{SC} \quad(\mathrm{r}=0.9842$, $\mathrm{p}<0.01), \quad 50 \% \mathrm{FS}-50 \% \mathrm{SC} \quad(\mathrm{r}=0.9432, \mathrm{p}<0.01)$ and $25 \%$ FS-75\%SC $(r=0.9479, \mathrm{p}<0.01)$ were found (Fig. 4). A correlation coefficient between turbidity measurements and TSS of 0.9 or greater, indicates, according to Sadar (1996) a workable relationship. Briggs et al. (2003) presented their results as a percentage of obscuration; making it difficult to compare their data with those generated in the present study. In addition, the output of their photovoltaic cell is inversely related to turbidity, requiring the transformation of their readings into percentages of obscuration. In our instrument (HMT), the output of the photoresistor is directly related to turbidity, which is intuitively more suitable, higher turbidity values corresponding to higher values of the device's output. 
Previous studies have been developed in order to calibrate customer-built turbidimeters applied to the monitoring of suspended sediment in streams. Lewis (1996) and Orwin; Smart (2005) used a continuously recording turbidimeter with an infrared light emitting diode (LED) as light source and obtained qualitatively similar sensitivity to that of our HMT, and found greater sensibility to clay and silt fractions than to sand fractions. The LED light source reduces the color interferences of samples (UNITED STATES, 1999), but for the purpose of our test, the color is part of the turbidity, because we seek to detect any substance that is resuspended by the organisms, no matter whether they be solids or dissolved substances. Furthermore, in our test, any initial color of the sediment/overlying water was eliminated by the substraction of the initial measurement from each subsequent one.

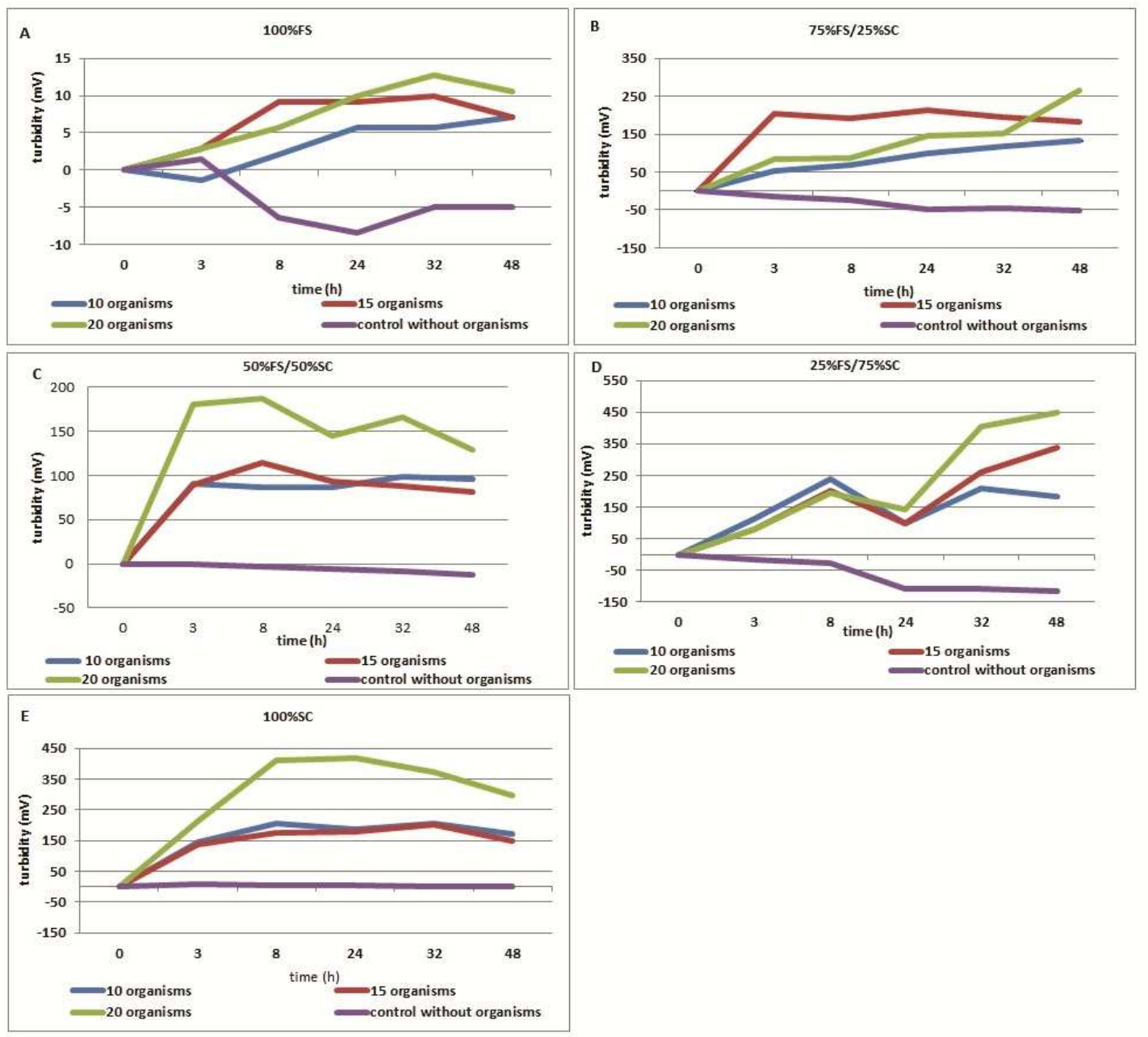

Fig. 3. Effect of density of organisms on turbidity for the sediments of different grain sizes. A) sediment $100 \%$ FS; B) sediment 75\% FS-25\% SC; C) sediment 50\% FS-50\% SC; D) sediment 25\% FS-75\% SC; E) sediment 100\% SC. Negative values correspond to decline of initial turbidity by settling, in the beakers without organisms. 

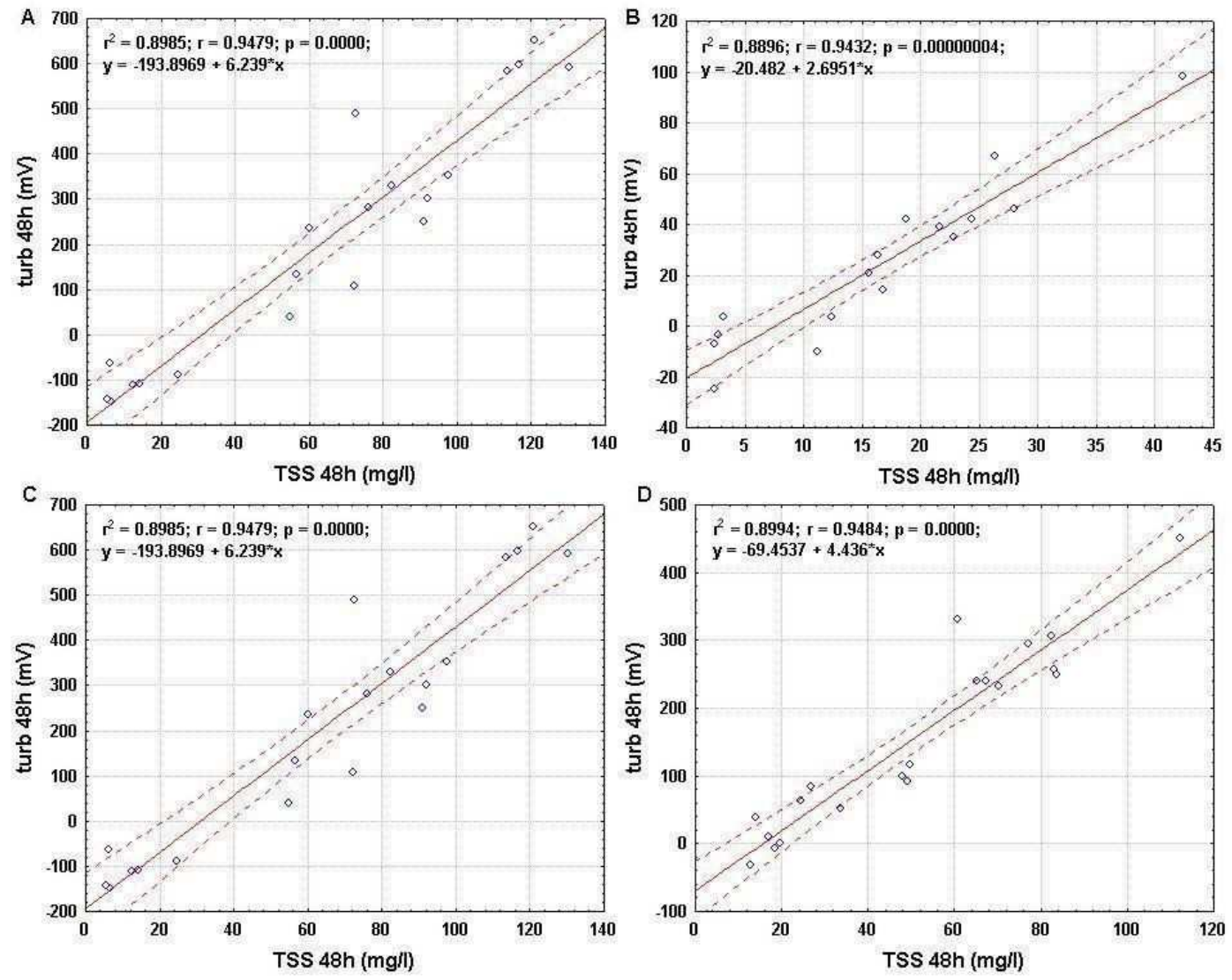

Fig. 4. Relationships between mean turbidity measured after 48 hours of exposition and TSS (total suspended solids). A) sediment 75\% FS-25\% SC; B) sediment 50\% FS-50\% SC; C) sediment 25\% FS-75\% SC; D) sediment 100\% SC. Best-fit equations are shown.

In conclusion, the instrument here described (HMT) is cheap and easy to construct and produces reliable measurements that can be easily applied to evaluation studies and monitoring programs of water quality. It can be accurately used for the determination of turbidity in exploratory sublethal tests of the toxicity of sediments with percentages of sand particles of less than $75 \%$.

\section{ACKNOWLEDGEMENTS}

The authors are grateful for the financial support provided by ANII (National Agency for the Investigation and Innovation of Uruguay) through the MSc. fellowship to MEB. PM also wishes to express his thanks to SNI-ANII. Marcos Montesano helped with the initial phases of the HMT construction. Special thanks to Felipe García and Ernesto Brugnoli for their kindly help with the collection of samples and to Eliana Korovsky for her help with the figures.

\section{REFERENCES}

ABRAHAMS, M. V.; KATTENFELD, M. G. The role of turbidity as a constraint on predator-prey interactions in aquatic environments. Behav. Ecol. Sociobiol., v. 40, n. 3, p. 169-174, 1997.

ALLEN, Y. T.; KIRBY, S. J.; REED, J.; THAIN, J. E. Development and application of chronic and sublethal sediment bioassays. 2000. 3rd World Conference of the Society of Environmental Toxicology and Chemistry, Brighton, UK. Disponível em: www.cefas.defra.gov.uk. Acesso em: 09 sept. 2013.

BARTSCH, M. R.; COPE, W. G.; RADA, R. G. Effect of cadmium-spiked sediment on cadmium accumulation and bioturbation by nymphs of the burrowing mayfly Hexagenia bilineata. Water, Air, Soil Pollut., v. 109, n. 1/4, p. 277-292, 1999.

BRIGGS, A. D.; GREENWOOD, N.; GRANT, A. Can turbidity caused by Corophium volutator (Pallas) activity be used to assess sediment toxicity rapidly? Mar. Environ. Res., v. 55, n. 3, p. 181-192, 2003. 
CARTER, M. W.; SHOUP, D. E.; DETTMERS, J. M. WAHL, D. H. Effects of turbidity and cover on prey selectivity of adult smallmouth bass. Trans. Am. Fish. Soc., v. 139, p. 353-361, 2010.

DAVIES-COLLEY, R. J.; SMITH, D. G. Turbidity, suspended sediment, and water clarity: a review. J. Am Water Resour. Assoc., v. 37, n. 5, p. 1085-1101, 2001

GIPPEL, C. J. The use of turbidimeters in suspended sediment research. Hydrobiologia, v. 176/177, n. 1, p. 465-480, 1989.

GONZALEZ, E. R. The freshwater amphipods Hyalella Smith, 1874 in Chile (Crustacea: Amphipoda). Rev. Chil. Hist. Nat., v. 76, p. 623-637, 2003

GRAÇA, M. A.; RODRÍGUES-CAPÍTULO, A.; OCÓN, C.; GÓMEZ, N. In situ tests for water quality assessment: a case study in Pampean rivers. Water Resour., v. 36, n. 16, p. 4033-4040, 2002.

JERGENTZ, S.; PESSACQ, P.; MUGNI, H.; BONETTO, C.; SCHULZ, R. Linking in situ bioassays and population dynamics of macroinvertebrates to assess agricultural contamination in streams of the Argentine pampa. Ecotoxicol. Environ. Saf., v. 59, n. 2, p. 133-141, 2004.

LEWIS, J. Turbidity controlled suspended sediment sampling for runoff-event load estimation. Water Resour. Res., v. 32, n. 7, p. 2299-2310, 1996.

RAND, G. M. WELLS, P. G.; MC CARTHY, L. S. Introduction to aquatic toxicology. In: RAND, G. M. (Ed.). Fundamentals of aquatic toxicology: effects, environmental fate, and risk assessment. 2.ed. Washington: Taylor and Francis, 1995. p. 3-67.

SADAR, M. J. Understanding turbidity science. [S.1.] Hach, 1996. 26 p. (Hach Company Technical Information Series - Booklet; n. 11).
ORWIN, J. F.; SMART, C. C. An inexpensive turbidimeter for monitoring suspended sediment. Geomorphology, v. 68 , n. $1 / 2$, p. $3-15,2005$. [53rd. Annual Meeting of the Canadian Associatino of Geographers].

UNITED STATES. Environmental Protection Agency. Determination of turbidity by nephelometry. Cincinnaty: Environmental Monitoring Systems Laboratory, Office of Research and Development, 1993. [Method 180.1].

UNITED STATES. Environmental Protection Agency. Guidance manual for compliance with the interim enhanced surface water treatment rule: turbidity provisions. Washington: Office of Water, 1999. [EPA 815-R-99-010]. Disponível

em: http://yosemite.epa.gov/water/owrccatalog.nsf/1ffc8769f decb48085256ad3006f39fa/484543f6ef92155a85256b06 00723b47! OpenDocument. Acesso em: 09 sept. 2013.

UNITED STATES. Environmental Protection Agency. Methods for measuring the toxicity and bioaccumulation of sediment-associated contaminants with freshwater invertebrates. 2.ed. Duluth, Washington: U.S. Environmental Protection Agency, 2000. 192 p. (EPA/600/R-99/064). Disponível em: http://water.epa.gov/polwaste/sediments/cs/upload/fresh manual.pdf. Acesso em: 09 sept. 2013.

(Manuscript received 24 September 2012; revised 16 June 2013; accepted 28 August 2013) 